\title{
DRIP IRRIGATION SYSTEM IS BEST IRRIGATION SYSTEM UNDER HIGH DENSITY ORCHARDS
}

\author{
J P Rathore \\ Department of Horticulture, \\ RCA, MPUAT-Udaipur, \\ Rajasthan, India \\ Amit Kumar, Anil Sharma \\ Div. of Fruit Science, \\ SKUAST-Kashmir, \\ Srinagar, JK, India
}

\begin{abstract}
Water is the most critical input in successful cultivation of fruits and for getting higher yield; however, its deficiency is one of the most important restricting factors in crop production in the world ${ }^{[1]}$. The most important natural influences which affect the water quantity are climate, water supply, soil and topography ${ }^{[6]}$. The water requirements of temperate fruit plantation have been reviewed ${ }^{[9]}$. There are many irrigation systems that are used for water management in high density fruit crops but drip irrigation system is most commonly used in high density orchards due to its high water saving efficiency i.e. about 60-70 per cent. Reported that under sprinkler irrigation system $5616.8 \mathrm{~L}$ of water was required by a 6-year old apple tree for two years however it was only 2921.1 L under drip irrigation system [5]. Equilibrium between water irrigation and fertilization determines good conditions of growth to avoid excesses of vigor and physiological disorders that could affect fruit yield and quality [7]. Many researchers have reported the higher application efficiency of drip irrigation system over the conventional basin irrigation systems as well as other traditional irrigation systems. Compared drip and basin irrigation systems in fruit orchards and found that there was water savings of $40-60 \%$ in drip irrigation system than basin irrigation method [14].
\end{abstract}

Keywords: ETc, High Density Orchard, Irrigation Methods and Water.

\section{INTRODUCTION}

Traditional orchards based on wide plantings yielded $5 t$ per ha, whereas modern orchards based on close plantings, dwarfing

\author{
Pawan K Nagar \\ Dept. of Horticulture \\ BACA, AAU, Anand, \\ Gujrat, India
}

\author{
Kalpana Choudhary, Manish Kumar Meena \\ College of Horticulture and Forestry, \\ Jhalawar, AU, Kota, \\ Rajasthan, India
}

rootstocks and effective canopy management yield upto 100t per ha ${ }^{[8]}$. The canopies of most orchard crops including those from temperate and tropical areas capture less than $70 \%$ of radiated light and intensive canopy management is required to maximize light interception and productivity ${ }^{[15]}$. The development of high-density orchards in temperate fruits are dependent on the development of small trees than can be pruned to maximize light interception and still remain productive. Early and higher yield is possible only due to high density plantation ${ }^{[11]}$.

\section{IRRIGATION SYSTEMS}

Irrigation systems are most suitable for their particular orchard with maximizing their efficiency. Two types of irrigation systems are available for irrigation in high density orchards.

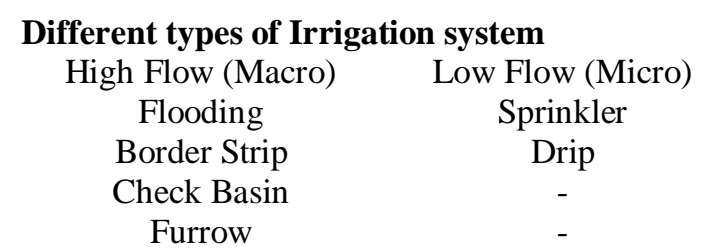

Drip Irrigation

- Drip irrigation is defined as the frequent application of small quantities of water directly above and below the soil surface; usually as discrete drops, continuous drops or tiny streams through emitters placed along a water delivery line.

- To apply sufficient moisture to the root of the crops- prevent water stress.

- A major difference between drip system and most other systems is that the balance between crop evapotranspiration and applied water.

- Also known as Trickle Irrigation. 


\section{International Journal of Engineering Applied Sciences and Technology, 2019 \\ Vol. 4, Issue 6, ISSN No. 2455-2143, Pages 182-186 \\ Published Online October 2019 in IJEAST (http://www.ijeast.com)}

\section{Need of drip irrigation}

- To make fruit crops productive.

- Help produce more from the available land, water and labor resources without either ecological or social harmony.

- Generate higher farm income, On-farm and off-farm employment.

- To use water efficiently.

- No water to runoff or evaporation and soil erosion.

- It reduces water contact with crop leaves, stems, and fruits.

- Agrochemicals can be applied more efficiently.

\section{BENEFITS OF DRIP IRRIGATION}

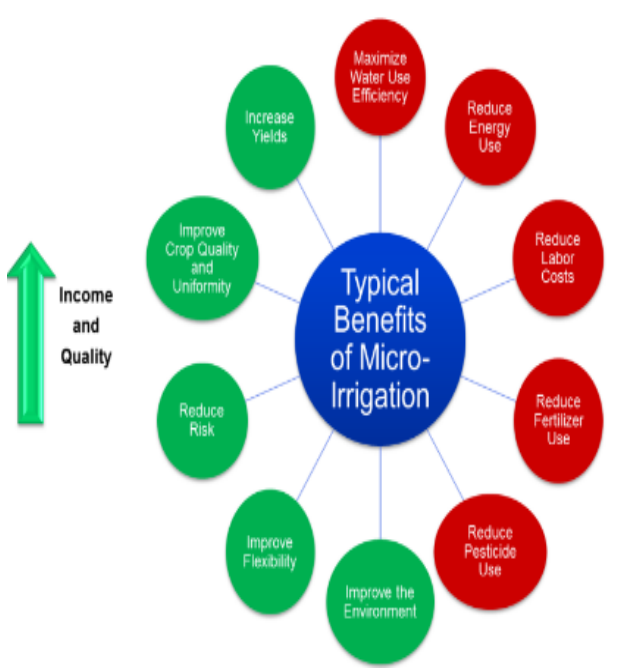

Figure 1 Benefits of drip irrigation Influence of various factors are used to water

$>$ Evapotranspiration

$>$ Temperature

$>$ Relative humidity

$>$ Wind

$>$ Radiant energy

Evapo-transpiration

Loss of water through living (plant part) or non-living surface (soil) is called as evapotranspiration.

\section{Temperature}

The degree or intensity of heat present in a substance or object. Depends on temperature, high temperature may cause high evapo-transpiration (high loss of water) while low temperature cause less evapo-transpiration (less water).

\section{Relative humidity}

.Wind

Amount of water vapour present in air.

Movement of air

Water loss depends on wind speed

Wind speed measure by- Anemometer

\section{How to calculate of water requirement to the plant}

Evaporation is the principle way of loss of water from the soil as well as plants. The evapotranspiration loss of water is treated as total water requirement of the plant. The requirement of water for a particular fruit crops is calculated using formula:

Table 1 Calculation of water requirement for fruit crops under high density orchards

\begin{tabular}{|c|c|c|c|c|c|}
\hline \multirow{2}{*}{$\begin{array}{l}\text { Age } \\
\text { of } \\
\text { the } \\
\text { plant }\end{array}$} & \multirow{2}{*}{$\begin{array}{c}\text { Spacing } \\
\text { (m) }\end{array}$} & \multicolumn{4}{|c|}{ Daily Water Uses in litres per Day } \\
\hline & & $\begin{array}{c}\text { E.T. } \\
0.10 " / \text { day } \\
\text { Cool } \\
\text { day, } \\
\text { early } \\
\text { spring } \\
\text { Late fall, } \\
\text { foggy }\end{array}$ & $\begin{array}{c}\text { E.T. } \\
0.20 " / \text { day } \\
\text { Warm } \\
\text { day in } \\
\text { spring } \\
\text { or fall; } \\
\text { some fog }\end{array}$ & $\begin{array}{c}\text { E.T. } \\
0.25 " / d a y \\
\text { Hot day, } \\
\text { mid- } \\
\text { summer } \\
\text { No fog }\end{array}$ & $\begin{array}{c}\text { E.T. } \\
0.30 " / d a y \\
\text { Very hot } \\
\left(100^{\circ} \mathrm{F}\right) \\
\text { Windy, } \\
\text { mid-- } \\
\text { summer }\end{array}$ \\
\hline \multirow{4}{*}{$\begin{array}{c}1 \\
\text { year } \\
\text { old }\end{array}$} & $3 \times 1$ & 0.960 & 1.920 & 2.40 & 2.88 \\
\hline & $3 \times 1.5$ & 1.44 & 2.88 & 3.60 & 4.32 \\
\hline & $3 \times 2$ & 1.92 & 3.84 & 4.80 & 5.76 \\
\hline & $3 \times 3$ & 2.88 & 5.76 & 7.20 & 8.64 \\
\hline \multirow{4}{*}{$\begin{array}{c}5 \\
\text { year } \\
\text { old }\end{array}$} & $3 \times 1$ & 4.8 & 9.6 & 12 & 14.4 \\
\hline & $3 \times 1.5$ & 7.2 & 14.4 & 18 & 21.6 \\
\hline & $3 \times 2$ & 9.6 & 19.2 & 24 & 28.8 \\
\hline & $3 \times 3$ & 14.4 & 28.8 & 36 & 43.2 \\
\hline
\end{tabular}

Compared two micro sprinkler irrigation systems in mature 'Fuji' trees in Washington State (Table 2). This difference is perhaps largely the result of the higher ETr and ETc values in Idaho than Washington ${ }^{[5]}$.

Table 2 Precipitation, evapo-transpiration and total volume of applied water per tree in Pacific Gala apple from 2004 to 2007

\begin{tabular}{|l|c|c|c|c|c|c|}
\hline Year & 2004 & 2005 & Mean & 2006 & 2007 & Mean \\
\hline $\begin{array}{l}\text { Precipitation } \\
\text { (mm) }\end{array}$ & 64.9 & 67.2 & 66.0 & 54.4 & 55.9 & 55.1 \\
\hline ETc (mm) & 846.3 & 930.7 & 888.7 & 1022.8 & 1077.7 & 1050.3 \\
\hline $\begin{array}{l}\text { Water } \\
\text { applied by } \\
\text { sprinkler } \\
\text { (lt./tree) }\end{array}$ & 5399.8 & 5833.8 & 5616.8 & 6249.9 & 6673.5 & 6461.7 \\
\hline $\begin{array}{l}\text { Water } \\
\text { applied by } \\
\text { drip (lt./tree) }\end{array}$ & 2404.2 & 3438.0 & 2921.1 & 3872.0 & 4121.2 & 3996.0 \\
\hline
\end{tabular}

Four year cumulative yield was recorded higher in drip system $(66.16 \mathrm{~kg} /$ tree $)$ as compare to sprinkler (64.25 kg/tree) (Table 3). Maximum yield 
efficiency has reported in drip system $\left(0.77 \mathrm{~kg} \mathrm{~cm}^{-2}\right)$ as compare to sprinkler system $\left(0.72 \mathrm{~kg} \mathrm{~cm}^{-}\right.$ ${ }^{2}$ ).Average fruit weights of four year in drip irrigation is $205.7 \mathrm{~g}$ while in sprinkler irrigation as 198.5 g. 'Pacific Gala' fruit from trees with sprinkler consistently had better color than those with a drip system every year that could be the result of the cooler temperatures that prevailed under trees with an sprinkler system. Also 'Pacific Gala' leaves from trees with sprinkler irrigation always had significantly lower magnesium $(\mathrm{Mg})$ than those on drip every year. Soluble solid concentration has no difference between both irrigation systems ${ }^{[5]}$.

Table 3 Effect of irrigation system on yield and physio-chemical characters during different age of tree in Pacific Gala/Bud.9

\begin{tabular}{|c|c|c|c|}
\hline \multirow[t]{2}{*}{ Characters } & \multirow[t]{2}{*}{ Year } & \multicolumn{2}{|c|}{ Irrigation methods } \\
\hline & & Sprinkler & Drip \\
\hline \multirow{5}{*}{$\begin{array}{l}\text { Yield } \\
\text { (kg/tree) }\end{array}$} & 2004 & 7.7 & 9.0 \\
\hline & 2005 & 6.2 & 9.8 \\
\hline & 2006 & 15.4 & 16.4 \\
\hline & 2007 & 35.2 & 30.3 \\
\hline & Cumulative & 64.2 & 66.1 \\
\hline \multirow{5}{*}{$\begin{array}{l}\text { Yield } \\
\text { efficiency } \\
(\mathrm{kg} / \mathrm{cm})\end{array}$} & 2004 & 0.52 & 0.69 \\
\hline & 2005 & 0.34 & 0.55 \\
\hline & 2006 & 0.63 & 0.73 \\
\hline & 2007 & 1.32 & 1.14 \\
\hline & Mean & 0.72 & 0.77 \\
\hline \multirow{5}{*}{$\begin{array}{l}\text { Average } \\
\text { fruit weight } \\
\text { (g) }\end{array}$} & 2003 & 206.8 & 219.1 \\
\hline & 2004 & 198.9 & 214.8 \\
\hline & 2005 & 199.0 & 198.2 \\
\hline & 2006 & 182.7 & 177.3 \\
\hline & Mean & 198.5 & 205.7 \\
\hline \multirow[t]{5}{*}{ Color } & 2004 & 3.9 & 3.5 \\
\hline & 2005 & 3.1 & 2.7 \\
\hline & 2006 & 4.0 & 3.7 \\
\hline & 2007 & 3.8 & 3.3 \\
\hline & Mean & 3.69 & 3.27 \\
\hline \multirow{5}{*}{$\begin{array}{l}\text { Soluble } \\
\text { solids }(\%)\end{array}$} & 2004 & 13.9 & 14.1 \\
\hline & 2005 & 14.5 & 14.0 \\
\hline & 2006 & 14.0 & 14.4 \\
\hline & 2007 & 13.5 & 13.2 \\
\hline & Mean & 14.0 & 14.0 \\
\hline
\end{tabular}

Table 5 Effect of drip irrigation treatments and rootstocks on physical quality parameters in apple cv. Red Fuji
A significantly greater volume of water is required for trees under full micro-sprinkler systems than those with drip systems. Application of water through a drip system, based on full ETc rate and adjusted by percentage of GS, can result in major water savings and often improves yield and fruit quality.

Compared four drip irrigation treatments (100\% ETc, $80 \%$ ETc, $60 \%$ ETc or $40 \%$ ETc) at weekly intervals ${ }^{[12]}$. The drip irrigation treatments were compared to basin irrigation (control) at $100 \%$ ETc. Two apple cultivars under study were Red Fuji and Scartlet Gala grafted on three rootstocks viz. EMLA-106, EMLA-7 and EMLA-111.

Table 4 Volume of water applied (in liters) various treatments during 2002-2003 and 2003-2004

\begin{tabular}{|l|c|c|c|c|}
\hline \multirow{2}{*}{$\begin{array}{l}\text { Water } \\
\text { Applied }\end{array}$} & \multicolumn{4}{|c|}{ Varieties } \\
\cline { 2 - 5 } & \multicolumn{2}{|c|}{ Red Fuji } & \multicolumn{2}{c|}{ Scarlet Gala } \\
\cline { 2 - 5 } & $2002-$ & $2003-$ & $2002-$ & $2003-$ \\
2003 & 2004 & 2003 & 2004 \\
\hline $100 \%$ ETc & 1144 & 1041 & 881 & 796 \\
\hline $80 \%$ ETc & 852 & 831 & 705 & 635 \\
\hline $60 \%$ ETc & 689 & 625 & 528 & 478 \\
\hline $40 \%$ ETc & 460 & 476 & 352 & 378 \\
\hline $\begin{array}{l}\text { Control } \\
\text { (Basin } \\
\text { Irrigation) }\end{array}$ & 1144 & 1041 & 881 & 796 \\
\hline
\end{tabular}

\section{Yield and Physical quality parameters}

The highest yield in Red Fuji was reported $12.95 \mathrm{~kg} /$ tree during 2003-2004 whereas 13.06 $\mathrm{kg} /$ plant reported in Scartlet Gala during 2003-2004. The effect has been widely referenced in literature [3]. Reported an increase of 40 to 60 percent in fruit size under high quantity of water applied through drip ${ }^{[2]}$. The scion grafted on EMLA-106 produced fruits with highest fruit length, diameter, weight and volume.

\section{Biochemical quality parameters}

During both the years of study, the plants under basin irrigation (control) produced fruits which were more firm and had highest total soluble solids than drip irrigation treatments except for $40 \%$ ETc which was at par with it. The TSS content in treatments $100 \%$ ETc, $80 \%$ ETc and $60 \%$ ETc was statistically at per during both the years.

\begin{tabular}{|c|c|c|c|c|c|c|c|}
\hline \multirow[t]{2}{*}{ Characters } & \multirow[t]{2}{*}{ Year } & \multirow[t]{2}{*}{ Rootstocks } & \multicolumn{5}{|c|}{ Treatments } \\
\hline & & & $100 \%$ ETc & $80 \%$ ETc & $60 \%$ ETc & $40 \%$ ETc & $\begin{array}{l}\text { Control } \\
\text { (Basin } \\
\text { Irrigation) }\end{array}$ \\
\hline \multirow{3}{*}{$\begin{array}{l}\text { Fruit length } \\
(\mathrm{cm})\end{array}$} & \multirow[t]{3}{*}{$2002-2003$} & EMLA 106 & 5.87 & 5.27 & 5.06 & 4.90 & 4.57 \\
\hline & & EMLA-7 & 5.57 & 5.3 & 4.78 & 4.60 & 4.27 \\
\hline & & EMLA-111 & 5.84 & 5.49 & 5.12 & 4.74 & 4.25 \\
\hline
\end{tabular}


International Journal of Engineering Applied Sciences and Technology, 2019

Vol. 4, Issue 6, ISSN No. 2455-2143, Pages 182-186

Published Online October 2019 in IJEAST (http://www.ijeast.com)

\begin{tabular}{|c|c|c|c|c|c|c|c|}
\hline & \multirow[t]{3}{*}{ 2003-2004 } & EMLA 106 & 6.2 & 5.85 & 5.22 & 5.13 & 4.74 \\
\hline & & EMLA-7 & 5.96 & 5.53 & 4.93 & 4.69 & 4.32 \\
\hline & & EMLA-111 & 5.69 & 5.01 & 4.90 & 4.35 & 4.26 \\
\hline \multirow{6}{*}{$\begin{array}{l}\text { Fruit } \\
\text { diameter } \\
\text { (cm) }\end{array}$} & \multirow[t]{3}{*}{$2002-2003$} & EMLA 106 & 7.41 & 7.06 & 6.47 & 5.91 & 5.45 \\
\hline & & EMLA-7 & 7.24 & 6.90 & 6.39 & 5.84 & 5.23 \\
\hline & & EMLA-111 & 7.11 & 6.59 & 6.03 & 5.46 & 5.08 \\
\hline & \multirow[t]{3}{*}{ 2003-2004 } & EMLA 106 & 7.54 & 7.11 & 6.57 & 6.13 & 5.63 \\
\hline & & EMLA-7 & 7.32 & 6.9 & 6.24 & 5.86 & 5.36 \\
\hline & & EMLA-111 & 7.34 & 6.87 & 6.16 & 5.89 & 5.36 \\
\hline \multirow{6}{*}{$\begin{array}{l}\text { Fruit weight } \\
\text { (g) }\end{array}$} & \multirow[t]{3}{*}{$2002-2003$} & EMLA 106 & 144.0 & 97.95 & 91.37 & 78.75 & 67.0 \\
\hline & & EMLA-7 & 108.7 & 99.25 & 83.75 & 76.12 & 67.0 \\
\hline & & EMLA-111 & 109.9 & 100.0 & 86.75 & 77.75 & 66.87 \\
\hline & \multirow[t]{3}{*}{$2003-2004$} & EMLA 106 & 117.8 & 109.7 & 98.14 & 87.20 & 77.90 \\
\hline & & EMLA-7 & 113.1 & 101.2 & 93.46 & 82.40 & 74.66 \\
\hline & & EMLA-111 & 112.3 & 105.2 & 94.19 & 85.40 & 74.30 \\
\hline \multirow{6}{*}{$\operatorname{TSS}\left({ }^{\circ} \mathrm{B}\right)$} & \multirow[t]{3}{*}{$2002-2003$} & EMLA 106 & 15.60 & 16.76 & 16.65 & 17.59 & 18.24 \\
\hline & & EMLA-7 & 16.39 & 17.37 & 17.60 & 18.44 & 18.51 \\
\hline & & EMLA-111 & 16.41 & 16.69 & 17.41 & 17.52 & 17.72 \\
\hline & \multirow[t]{3}{*}{ 2003-2004 } & EMLA 106 & 16.14 & 16.41 & 16.66 & 16.90 & 17.48 \\
\hline & & EMLA-7 & 16.41 & 16.58 & 16.79 & 17.19 & 17.67 \\
\hline & & EMLA-111 & 16.47 & 16.63 & 16.89 & 17.27 & 17.65 \\
\hline \multirow[t]{6}{*}{ Acidity (\%) } & \multirow[t]{3}{*}{$2002-2003$} & EMLA 106 & 0.35 & 0.37 & 0.40 & 0.42 & 0.45 \\
\hline & & EMLA-7 & 0.34 & 0.33 & 0.35 & 0.38 & 0.42 \\
\hline & & EMLA-111 & 0.27 & 0.32 & 0.32 & 0.37 & 0.42 \\
\hline & \multirow[t]{3}{*}{ 2003-2004 } & EMLA 106 & 0.36 & 0.40 & 0.42 & 0.44 & 0.47 \\
\hline & & EMLA-7 & 0.43 & 0.44 & 0.46 & 0.46 & 0.54 \\
\hline & & EMLA-111 & 0.41 & 0.42 & 0.47 & 0.49 & 0.51 \\
\hline \multirow{6}{*}{$\begin{array}{l}\text { Total Sugar } \\
(\%)\end{array}$} & \multirow[t]{3}{*}{$2002-2003$} & EMLA 106 & 7.29 & 7.34 & 7.49 & 7.95 & 7.97 \\
\hline & & EMLA-7 & 7.26 & 7.26 & 7.38 & 7.84 & 7.84 \\
\hline & & EMLA-111 & 7.20 & 7.27 & 7.39 & 7.83 & 7.85 \\
\hline & \multirow[t]{3}{*}{ 2003-2004 } & EMLA 106 & 7.47 & 7.61 & 7.95 & 8.11 & 8.10 \\
\hline & & EMLA-7 & 7.37 & 7.53 & 7.81 & 7.91 & 8.00 \\
\hline & & EMLA-111 & 7.33 & 7.51 & 7.79 & 7.89 & 7.90 \\
\hline
\end{tabular}

The possible reasons for higher TSS content in $40 \%$ ETc and control may be the lower moisture level at root zone which caused lower fruits size and consequently higher proportion of sugars. Higher fruit firmness in the trees receiving low volume of water was also reported ${ }^{[10]}$ and ${ }^{[4]}$. Reported that acidity in fruit juice increased by applying irrigation ${ }^{[13]}$. There was a little difference among varieties for biochemical parameters except for TSS and Total sugars which were higher in Scarlet Gala.

\section{CONCLUSION}

High density orchards require less irrigation water as compared to the traditional system of planting which is to be supplied either by drip irrigation system or micro sprinkler irrigation system. Due to shallow root system of the clonal rootstock frequent water is needed to obtain optimum fruit yield and quality. Permanent drip irrigation system in high density orchards during the growing seasons distinctly increases tree vigour and fruit yield and quality. Application of water through a drip system, based on full ETc rate and adjustment in $G_{w}, A_{w}$ and $P_{e}$ can result in major water savings. With an increase in area in high density orchards, use of drip irrigation system and new clonal rootstocks have profound effect on fruit quality and yield of fruit plants which further needs to be studied.

\section{REFERENCES}

[1] N.A. Akram, M. Shahbaz and M. Ashraf. Relationship of photosynthesis capacity and proline accumulation with the growth of differently adapted population of two potential grasses (Cydonondactylon L. and Cenchrusciliaris L.) to drought stress. Pak. J. Bot., (pp. 777-786, 2007).

[2] A. Albari, L. Lanzone and P. Mannini. Experiment of drip irrigation on apple trees. Fruitticulture, (pp. 17-24, 1982).

[3] A. Berganiani. Lirrigazionedellepomace. In Lirrigazionedeve Colture Ortofrutticole. (pp. 151-176, 1988). 
[4] J. Bonany and F. Camps. Effect of different irrigation levels on apple fruit quality.Acta Horticulturae, (pp. 47-52, 1998).

[5] E. Fallahi, B. Fallahi and B. Shafii. Irrigation and rootstock influence on water use, tree growth, yield, and fruit quality at harvest at different ages of trees in 'Pacific Gala' apple. HortScience, (pp. 588-593, 2013).

[6] F.B. Harry. Irrigation engineer Soil and Water Conservation Research Division, Agricultural Research Service, United States Department of Agriculture, 1962.

[7] H.E. Holzapfel, G.G. Figueroa, V.A. Venegas and C. R. Matta. Requerimien to shídricosenmanzanosadultos. Agro Ciencia, (pp. 49-54, 1995).

[8] J.E. Jackson. World-wide development of high density planting in research and practice. ActaHorticulturae, (pp. 17-27, 1989).

[9] J.J. Landsberg and H.G. Jones. Apple orchards. In: Water Deficits and Plant Growth, (Ed.): T.T. Kozlowski. Academic Press, New York, (pp. 419-469, 1981).

[10] J.R. Morris, A.A. Kattan and E.A. Arrington. Response of Elberta peaches to the interactive effects of irrigation, pruning and thinning. Proc. Amer. Soc. Hort. Sci., (pp. 177-189, 1962).

[11] I. Ninkovski. Advantages of high density peach orchard. NaukaProski, (pp. 419-430, 1983).

[12] A.S. Rehallia, S.K. Banyal and V.S. Rona. Effect of drip irrigation and rootstocks on apple under high density plantation. Temperate Horticulture: Current Scenario, pp. 333-339, 2004.

[13] R.C. Rom.Apple irrigation studies. ArknsFm Research, (pp. 8, 1965).

[14] S. Salvin, K. Baruah and S.K. Bordoloi. Drip irrigation studies in banana cv. Barjahaji (Musa AAA group, Cavendish sub-group). Crop Research, (pp. 489-493, 2000).

[15] A.W. Whiley, B.N. Wolstenholme, and B.A. Faber.Crop management. In: Schaffer, B., Wolstenholme, B.N. and Whiley, A.W. (eds.). The Avocado: Botany, Production and Uses. CABI, Wallingford, UK, (pp. 342-379, 2013). 